\title{
A DIGITAL PANORAMIC RADIOGRAPH STUDY OF LENGTH OF STYLOID PROCESS IN NEPALESE POPULATION
}

\author{
Arun Dhakal ${ }^{* 1}$, Sushma Pandey ${ }^{2}$. \\ ${ }^{{ }_{1}}$ Assistant Professor, Department Of Anatomy, Chaitwan Medical College, Nepal. \\ ${ }^{2}$ Associate Professor, Department Of Oral Medicine And Maxillo Facial Radiology, Bpkihs, Dharan, \\ Nepal.
}

\section{ABSTRACT}

Introduction and Objectives: The mean radiographic length of the styloid process has been reported to be between 20 to $30 \mathrm{~mm}$. Although the reason for its variable development is not clear, elongation of the styloid process is recognized as one of the numerous causes of pain in the craniocervical region. Length of the styloid process in the Nepalese population has not been carried extensively to date. With this in mind our study aims to measure the length of styloid process on panoramic radiographs and determine the variation in age, sex and sides of the elongated styloid process.

Material and methods: A total of 200 digital panoramic radiographs which were available as soft copies in the department of Oral and Maxillofacial Radiology, Chitwan Medical College, were selected for the study. The unpaired $\mathrm{t}$ test, and two-way ANOVA were used for statistical analysis.

Results: Elongated styloid processes were present in $36 \%$ of the panoramic radiographs. The mean lengths of the elongated right and left styloid processes were $33.57 \pm 6.02 \mathrm{~mm}$ and $36.21 \pm 6.47 \mathrm{~mm}$, respectively and the difference between them was statistically significant. Mean length of the right and left side styloid processes in males was $33.37 \pm 6.5 \mathrm{~mm}$ and $36.41 \pm 7.3 \mathrm{~mm}$, whereas in females it was $34.24 \pm 6.24 \mathrm{~mm}$ and $37.01 \pm 6.12 \mathrm{~mm}$ respectively.

Conclusion: Elongated styloid process is frequently seen in the elderly population with no correlation to gender. KEY WORDS: Elongated styloid process, panoramic radiography, Age group.

Address for Correspondence: Dr. Arun Dhakal Assistant Professor, Department Of Anatomy, Chaitwan Medical College, Nepal. E-Mail: arund@mail.ru

\section{Access this Article online}

\section{Quick Response code}

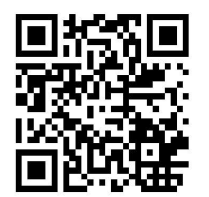

DOI: $10.16965 /$ ijar.2017.122

Web site: International Journal of Anatomy and Research

ISSN 2321-4287

www.ijmhr.org/ijar.htm

Received: 20 Jan 2017

Peer Review: 20 Jan 2017

Revised: None
Accepted: 24 Feb 2017

Published (O): 31 Mar 2017

Published (P): 31 Mar 2017

\section{INTRODUCTION}

The styloid process (SP) is slender and pointed, and projects anteroinferiorly from the inferior aspect of the temporal bone. Its length varies, ranging from a few millimetres to an average of $2.5 \mathrm{~cm}$.arises [1]. The styloid process develops from Reichert's cartilage of the second brachial arch [2]. The stylohyoid, stylopharyngeus, and stylogossus muscles, together with stylomandibular ligament attaches to this structure [1].
The length of the styloid process measures usually around 2 to $3 \mathrm{~cm}$. When more than $3 \mathrm{~cm}$ it is called an elongated styloid process causing dull pain in the ears, throat or mastoid region, difficulty in swallowing, foreign body sensation, symptoms of temperomandibular dysfunction like limited or asymmetric jaw movements or even carotid artery compression syndrome with rare cases of strokes [3- 8]. Long styloid process was first described in 1652 by 
Italian surgeon Pietro Marchetti. In 1937, Watt W Eagle coined the term stylalgia to describe the pain associated with elongation of styloid process [9]. In $4 \%$ of the general population styloid process is grossly enlarged. Although $4 \%$ of the population is thought to have an elongated styloid, only 4 to $10 \%$ of this group is symptomatic [9-13]. Panoramic radiograph is one of the most useful techniques that show the styloid process. It is frequently used for routine dental examinations and is a useful tool for early diagnosis of elongated styloid processes and referring the patients forward for additional tests [14]. Various studies have been conducted on its length and abnormal elongation in different geographical regions [15-19]. The purpose of this study was to evaluate the elongation of styloid process by using digital panoramic radiographs.

\section{MATERIALS AND METHODS}

This study involved a total of 200 digital panoramic radiographs which were available as soft copies in the department of Oral and Maxillofacial Radiology, Chitwan Medical College, of patients referred for radiography in the department. The selected radiographs were of patients above 10 years of age. Radiographs not showing or partially showing the styloid processes and having positioning and magnification errors were excluded from the study during the selection process. These radiographs were taken with a digital panoramic system (Gendex Orthoralix 9200) that used a fiber optic charged couple device (CCD) sensor as the image receptor. Exposure parameters used for the digital panoramic machine were $66 \mathrm{kVp}, 12$ $\mathrm{mA}$ current with an exposure time of 12 seconds as recommended by the manufacturer. The approximate length of the styloid process was measured with the help of the measurement tools accompanying the software (VixWin ${ }^{\mathrm{TM}}$ Platinum, Version 2). The magnification factor used for the machine was 1.27. The lengths of the styloid process were measured on its anterior aspect from the point of emergence of the process to their tips, regardless of whether or not the styloid process was segmented (Fig 1). Both unilateral and bilateral measurements were made and the prevalence of the same was recorded (Fig 2, Fig 3). The radiographs were measured by two experts who were blinded to the study. The study of radiographs was performed in a room with dimmed light.

The data was analyzed using SPSS software package for Windows version 16.0 . Values were expressed as mean and standard deviation. Student t-test and ANOVA were used to test the difference between mean elongation for the gender, age and the side affected. A p-value of less than 0.05 was considered statistically significant.

Fig. 1: Bilaterally elongated styloid process measured on its anterior aspect.

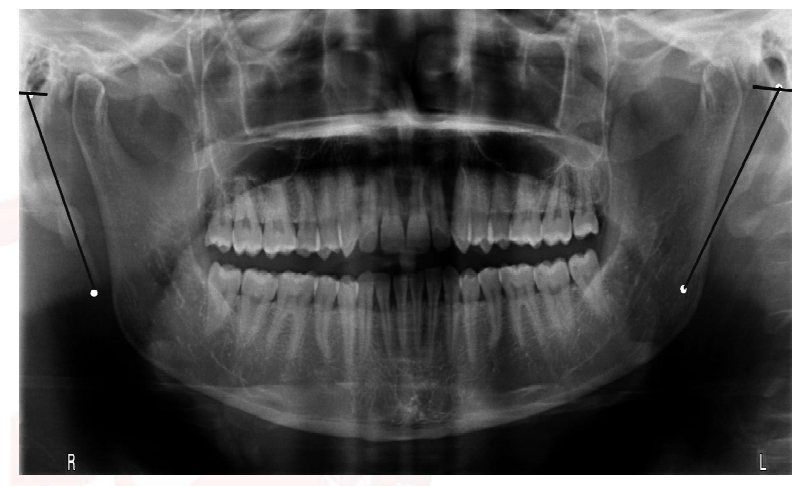

Fig. 2: Figure showing unilateral styloid process.

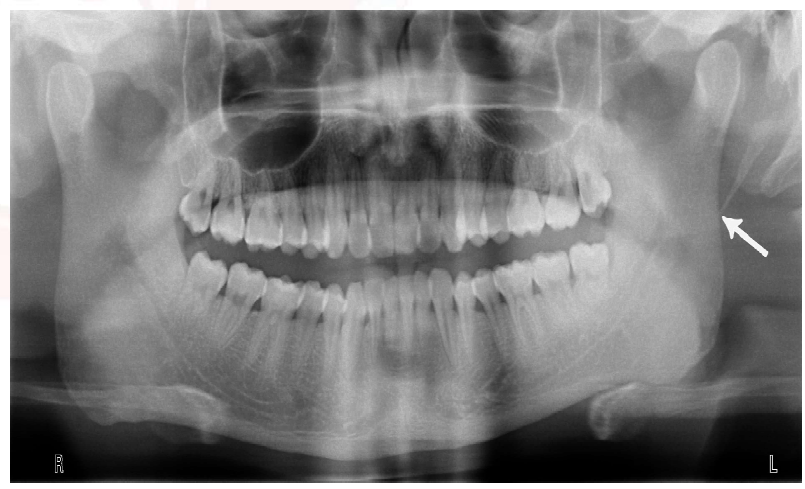

Fig. 3: Figure showing bilateral styloid process.

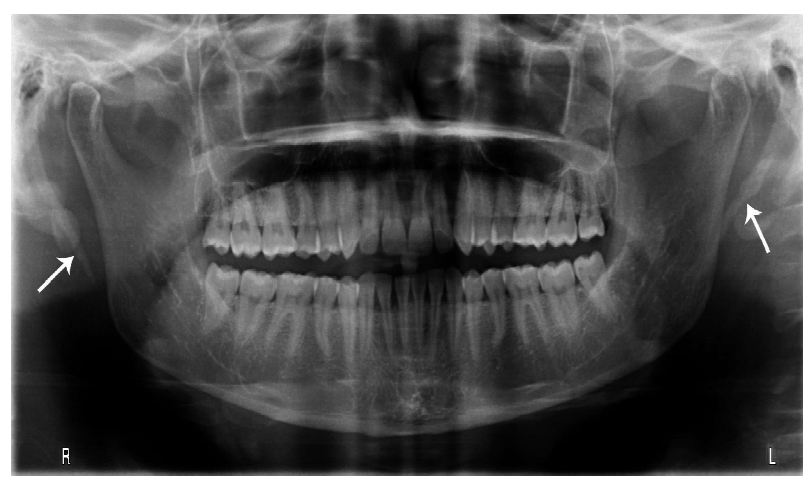

RESULTS

The radiographs of 200 patients were aged between 10 and 80 years. In Table 1 length of the styloid process shows a positive correlation with age. Out of 200 there were 72 radiographs 
with elongated styloid process. The mean lengths of the elongated right and left styloid processes were $33.57 \pm 6.02 \mathrm{~mm}$ and $36.21 \pm$ $6.47 \mathrm{~mm}$, respectively [Table-2]. Age group between $21-30$ years has a significantly smaller elongated styloid process than the other age groups [Table-3]. Length of the styloid process in relation to gender was insignificant [Table 4]. Out of the 200 radiographs, 52 showed bilateral elongation of the styloid process and 20 showed unilateral elongated styloid processes (12 on the right side and 8 on the left side) [Table 5]. Thus, 72 panoramic radiographs (36\%) showed at least one elongated styloid process.

Table 1: Mean Length of the styloid process in different age groups.

\begin{tabular}{|c|c|c|c|}
\hline \multirow{2}{*}{ Age group } & \multirow{2}{*}{$\begin{array}{c}\text { Number } \\
(\%)\end{array}$} & \multicolumn{2}{|c|}{ Average length of the styloid (mm) } \\
\cline { 3 - 4 } & & LEFT SIDE & RIGHT SIDE \\
\hline$\leq 20$ & $5(2.5)$ & $28.90 \pm 3.21$ & $27.94 \pm 3.08$ \\
\hline $21-30$ & $40(20)$ & $29.62 \pm 4.01$ & $28.87 \pm 3.72$ \\
\hline $31-40$ & $59(29.5)$ & $29.75 \pm 7.60$ & $28.95 \pm 5.77$ \\
\hline $41-50$ & $36(18)$ & $30.32 \pm 7.67$ & $29.80 \pm 6.58$ \\
\hline $51-60$ & $33(16.5)$ & $31.62 \pm 6.35$ & $29.4 \pm 7.61$ \\
\hline $61-70$ & $19(9.5)$ & $32.46 \pm 6.15$ & $30.34 \pm 7.88$ \\
\hline$>70$ & $8(4)$ & $33.12 \pm 6.47$ & $31.54 \pm 8.5$ \\
\hline
\end{tabular}

Table 2: Mean length of the left and right elongated styloid processes.

\begin{tabular}{|c|c|c|c|c|}
\hline \multirow{2}{*}{ Side } & \multirow{2}{*}{$\begin{array}{c}\text { Number } \\
(\%)\end{array}$} & \multicolumn{3}{|c|}{$\begin{array}{c}\text { Average length of } \\
\text { styloid (mm) }\end{array}$} \\
\cline { 3 - 5 } & & Mean & SD & SEM \\
\hline Right & $64(51.61)$ & 33.57 & 6.02 & 0.83 \\
\hline Left & $60(48.38)$ & 36.21 & 6.47 & 0.752 \\
\hline \multicolumn{5}{|c|}{ P value: 0.020} \\
\hline
\end{tabular}

SD- standard deviation, SEM- Standard error of mean Table 3: Difference between the mean elongations of styloid process according to age group.

\begin{tabular}{|c|c|c|c|}
\hline $\begin{array}{c}\text { Age group } \\
\text { (Years) }\end{array}$ & sample $(\mathrm{n})$ & mean \pm SD & significance \\
\hline $21-30$ & 9 & $32.01 \pm 1.88$ & $\mathrm{c}, \mathrm{b}$ \\
\hline $31-40$ & 14 & $34.5 \pm 2.16$ & $\mathrm{a}$ \\
\hline $41-50$ & 17 & $35.22 \pm 0.89$ & $\mathrm{a}$ \\
\hline $51-60$ & 18 & $35.06 \pm 1.79$ & $\mathrm{a}, \mathrm{c}$ \\
\hline $61-70$ & 9 & $36.43 \pm 1.62$ & $\mathrm{a}$ \\
\hline$>70$ & 5 & $37.64 \pm 0.54$ & $\mathrm{a}, \mathrm{b}, \mathrm{c}$ \\
\hline
\end{tabular}

a: difference statistically significant with age group 21-30 years

b: difference statistically significant with age group 31-40 years

c: difference statistically significant with age group 41-50 years
In the 200 radiographs studied, a total of 400 styloid processes were evaluated. Out of these, 124 styloid (31\%) were elongated [64 on the right side $(51.61 \%)$ and 60 on the left side (48.38\%)] [Table 2].

Elongated styloid processes were more prevalent in the age group of $51-60$ years and in those $>70$ years of age [Table 3].

Table 4: Mean length of the elongated left and right styloid processes in the two sexes.

\begin{tabular}{|c|c|c|c|}
\hline \multirow{2}{*}{ Gender } & \multirow{2}{*}{$\begin{array}{c}\text { Number } \\
(\%)\end{array}$} & \multicolumn{2}{|c|}{$\begin{array}{c}\text { Average length of the styloid } \\
(\mathrm{mm})\end{array}$} \\
\cline { 3 - 4 } & & LEFT SIDE & RIGHT SIDE \\
\hline Male & 38 & $36.41 \pm 7.3$ & $33.37 \pm 6.6$ \\
\hline Female & 34 & $37.01 \pm 6.12$ & $34.24 \pm 6.24$ \\
\hline \multicolumn{2}{|c|}{ P value: } & 0.7 & 0.56 \\
\hline
\end{tabular}

Table 5: The percentage distribution of unilateral and bilateral elongation of styloid process.

\begin{tabular}{|c|c|c|c|c|}
\hline \multirow{2}{*}{ Gender } & \multicolumn{2}{|c|}{ Unilateral } & \multicolumn{2}{c|}{ Bilateral } \\
\cline { 2 - 5 } & $\mathbf{N}$ & $\%$ & $\mathbf{N}$ & $\%$ \\
\hline Male & 15 & 39.47 & 23 & 60.52 \\
\hline Female & 5 & 14.7 & 29 & 85.29 \\
\hline Total & 20 & 27.7 & 52 & 72.22 \\
\hline
\end{tabular}

\section{DISCUSSION}

The morphological characteristics of the SP have been studied by several researchers $[5,3,17$, $20,21]$ using different methodologies. The results of these studies show that the prevalence of elongated styloid process varies between $0,4-84,4 \%$ of the population. The result of our study (36\%) is in agreement with the literature. Various outcomes could be due to dissimilarity in the age group and sample size. Comparing the outcomes of the prevalence of elongated styloid process is impossible because of racial, ethnical, anatomical variations, differences in the procedure of measurement devices and observer variation. Study suggests that panoramic radiograph are a suitable tool for epidemiological studies [21] though precise evaluation using two-dimensional radiographic as panoramic radiographs could be challenging due considerations like projection, magnification and distortion of the styloid process [21].

Elongated styloid process is often asymptomatic, and its pathogenesis is still unknown. Various hypotheses include ossification of the 
stylohyoid ligament, reactive metaplasia/ hyperplasia, anatomic variation, ageing, developmental anomaly and trauma leading to loss of elasticity in the stylohyoid ligament [21]. Our result suggests that elongated styloid process is common in elderly people which may be due to the calcification of the stylohyoid ligament with aging [22]. Also left sided elongated styloid processes were significantly much longer than the right sided elongated styloid processes. Concerning gender no statistically significant variation was observed in the unilateral, bilateral or overall elongation of the styloid process which is in agreement with other studies [4, 23].

\section{CONCLUSION}

This study provides a data on elongated styloid process of Nepalese population visiting a tertiary center in the mid western part of Nepal. Elongated styloid process is commonly seen in the elderly people with no association to gender.

\section{Conflicts of Interests: None}

\section{REFERENCES}

[1]. Standring Susan. GRAY'S Anatomy (The Anatomical Basis of Clinical Practice). External and middle ear. 41th ed. Churchill Livingstone; 2016:626.

[2]. Sadler T.W. Langman's Medical Embryology. Head and Neck. $11^{\text {th }}$ ed. Lippincott Williams \& Wilkins; 2011;269.

[3]. Correll RW, Jensen JL, Taylor JB, Rhyne RR. Mineralization of the stylohyoid-stylomandibular ligament complex: A radiographic incidence study. Oral Surg Oral Med Oral Pathol. 1979 Oct;48(4):286-91.

[4]. Ýlgüy $M$, Ýlgüy D, Güler N, Bayirli G. Incidence of the type and calcification patterns in patients with elongated styloid process. J Int Med Res 2005 JanFeb;33(1):96-102.

[5]. Kaufman SM, Elzay RP, Irish EF. Styloid process variation: radiologic and clinical study. A Arch Otolaryngol 1970 May;91(5):460-3.

[6]. Krennmair G, Piehslinger E. Variants of ossification in the stylohyoid chain. Cranio 2003 Jan;21(1):31-7.

[7]. Gokce C, Sisman Y, Sipahioglu M. Styloid Process Elongation or Eagle's Syndrome: Is There Any Role for Ectopic Calcification? Eur J Dent 2008 Jul;2(3):224-8.

[8]. Bernhardt O, Gesch D, Schwahn C, Bitter K, et al. Signs of temporomandibular disorders in tinnitus patients and in a population-based group of volunteers: results of the Study of Health in Pomerania. J Oral Rehabil 2004 Apr;31(4):311-9.

[9]. EAGLE WW. Elongated styloid process: symptoms and treatment. AMA Arch Otolaryngol 1958 Feb;67(2):172-6.
[9]. EAGLE WW. Elongated styloid process: symptoms and treatment. AMA Arch Otolaryngol 1958 Feb;67(2):1726.

[10]. Dinkar, Amonkar SS. Eagle's syndrome: Review of literature and case report. Indian J Dent Res 2003;14:162-68.

[11]. Prabhu LV, Kumar A, Nayak, et al. An unusually lengthy styloid process. Singapore Med J 2007;48(2):e34-36.

[12]. Kim E, Hansen K, Frizzi J. Eagle syndrome: Case report and review of literature. Ear Nose Throat J 2008;87:631-33.

[13]. Kolagi SI, Herur A, Mutalik A. Elongated styloid process-report of two rare cases. International Journal of Anatomical Variations 2010;3:100-102.

[14]. Faivre A, Abdelfettah Z, Rodriguez S, Nicoli F. Bilateral internal carotid artery dissection due to elongated styloid processes and shaking dancing. J Neurol Neurosurg Psychiatry 2009 Oct;80(10):1154-5. doi: 10.1136/jnnp.2008.

[15]. Zangouei Booshehri M, Ezoddini Ardakani F, Rasooli A, Sarayedar Baser R, et al. Incidence of Stylohyoid Ligament Calcification and Its Length in an Iranian Adult Population. The Journal of Shahid Sadoughi university of Medical Sciences 2011, 19(2): 211-218.

[16]. Kosar M, Atalar M, Sabanclogullari V, Tetiker $H$, et al. Evaluation of the length and angulation of the styloid process in the patient with pre-diagnosis of Eagle syndrome. Folia Morphol (Warsz) 2011 Nov;70(4):295-9.

[17]. More CB, Asrani MK. Evaluation of the styloid process on digital panoramic radiographs. Indian J Radiol Imaging 2010 Nov; 20(4): 261-265.

[18]. Shaik MA, Naheeda SMK, Wahab A, Hameed S. Prevalence of elongated styloid process in Saudi population of Aseer region. Eur J Dent 2013 Oct;7(4):449-54. doi: 10.4103/1305-7456.120687.

[19]. Ghafari R, Dalili Z, Abdolahpur S. A study on the frequency of elongated styloid process and eagle's syndrome among patients admitted to Guilan dental school clinic (2005-2006). 2010.

[20]. Marçal Vieira EM, Guedes OA, De Morais S, De Musis $C R$, De Albuquerque PAA et al. Prevalence of elongated styloid process in a central Brazilian population. J Clin Diagn Res 2015; 9: ZC90-ZC92.

[21]. Bagga MB, Kumar CA, Yeluri G. Clinicoradiologic evaluation of styloid process calcification. Imaging Science in Dentistry. 2012; 42:155-61.

[22]. Jaju PP, Suvarna P, Parikh N. Eagles syndrome. An enigma to dentists. J Indian Acad Oral Med Radiol 2007;19:424-9.

[23]. Ferrairo VF, Sigurta D, Daddona A, Dalloca L, Miani A, Tafuro F, Sforza C. Calcification of the stylohyoid ligament: Incidence and morphoquantitative evaluations. Oral Surg Oral Med Oral Pathol. 1990;69:520-9.

How to cite this article:

Arun Dhakal, Sushma Pandey. A DIGITAL PANORAMIC RADIOGRAPH STUDY OF LENGTH OF STYLOID PROCESS IN NEPALESE POPULATION. Int J Anat Res 2017;5(1):36183621. DOI: 10.16965/ijar.2017.122 